\title{
School Mapping And The Universalization Of Basic Education In Imo State, Nigeria
}

\author{
Kenneth K. Obasi, Ph.D \\ Department of Educational Management \\ Faculty of Education \\ University of Port-Harcourt \\ Onyewuchi M. Madu \\ Department of Educational Management \\ Faculty of Education \\ University of Port-Harcourt
}

\begin{abstract}
The study investigated school mapping and the universalization of basic education in Imo State. Two research questions and two hypotheses guided the study. The study adopted the descriptive survey design. The population of the study was 1,777 consisting of 1,276 Head Teachers, 216 staff of the Imo State Universal Basic Education Board (IMSUBEB) and 285 staff of the Ministry of Education (MoE). The sample size was 327 which is $18.4 \%$ of the population. This consisted of 193 head teachers, 64 staff of IMSUBEB and 70 staff of MoE. These were selected using the stratified random sampling technique and the simple random sampling technique respectively. A questionnaire titled: School Mapping and the Universalization of Basic Education Questionnaire (SMUBEQ) was used for data collection. It was validated by experts in Educational Management and Measurement and Evaluation. The reliability was determined through the use of test-retest approach, using the Pearson's Product Moment Correlation Statistics with a reliability index of 0.84 . Mean and Standard Deviation were used to analyze the data while z-test statistics was used to test the hypotheses at 0.05 level of significance. The findings revealed among others that the level of primary school mapping since the implementation of UBE programme was low because it was carried out only on sampled subzones. The study recommended among others that the Government should as a matter of necessity carry out comprehensive school mapping to cater for the demand effect of the UBE programme.
\end{abstract}

Key words: School mapping, Universalization and Basic education

\section{INTRODUCTION}

Education is critical to the emancipation of an individual and a country from the murky waters of illiteracy, poverty and subjugation. In other words, it is a powerful instrument for development and economic prosperity through the development of the latent capacities in man, equipping him with the relevant skills, knowledge, attitudes and capacities necessary for a productive economic life. One cannot imagine the development of a nation when the supposed key actors (the people) of development are predominantly illiterate, underdeveloped and poor. Education equips the beneficiaries with relevant skills, knowledge and attitude to be productive; so as to contribute to the nation's development. On this premise therefore, the United Nations (UN), through the Universal Declaration of Human Rights (UDHR) of 1948, declared education 'a right of everyone'. This provided the first launching pad for other Conventions and Declarations on education as a fundamental right to every person that should be made accessible to all without discrimination. 
The other Conventions and Declarations that gave credence to this great course universalization of basic education include: the 1990 Jomtien Declaration which specifically engineered the promotion of equal basic education for all(EFA), the 1991 New Delhi Declaration which called for stringent efforts by those nine countries of the world with the largest concentration of illiterate populace, commonly referred to as 'E-9 countries' (of which Nigeria is one), to drastically reduce illiteracy within the shortest time frame; the World Education Forum held in Dakar, Senegal in 2000, where 164 governments across the globe pledged to achieve Education for All (EFA) by the year 2015 and the Millennium Development Goals (MDGs) 2001 which provided the platform and basis for the Universal Basic Education (No. 2). This was further boosted by the Organization of African Unity (OAU) now African Union (AU) that mandated African States to generalize access to quality basic education as a necessary foundation for sustainable socio-economic development. The general objective behind their respective educational programmes was basically to provide unhindered access to basic education.

The universalization of basic education is a global strategy designed to meet the basic learning needs of individuals irrespective of their gender, race, religion any perceived challenges or differences in birth circumstances. It was meant to help the beneficiaries to survive, develop their full capacities, live and work in dignity, participate fully in development, improve the quality of their lives, to make informed decisions and also to continue learning (World Conference on Education, 1990). This education programme, led to the broadening of the scope of the right to education. Its 'expanded vision' was proposed to enable everybody, children, youth, and adults, to meet their basic learning needs. By this, governments are obliged to make education, at least at the basic level, free, accessible, acceptable and adaptable.

Sequel to this, the Federal Government of Nigeria, introduced the Universal Basic Education (UBE) programme in 1999 which replaced the 1976 Universal Primary Education (UPE) which was limited to primary education. The UBE programme is a policy reform measure of the Federal Government of Nigeria, aimed at rectifying distortions in the basic education (FRN, 2004). It is designed to ensure unfettered access to free and compulsory education and exposure of its teeming youths to basic skills and literacy. The UBE programme is a deliberate effort to equip the Nigerian child with basis knowledge, skills, attitudes and capacities to be useful, productive and contribute to national development. Basic education in the Nigerian context entails six years of primary education and three years of junior secondary education for all children. This study, however, was delimited to primary education.

Primary education is the largest and the most fundamental component of basic education. It is the foundation upon which other the levels of education are built and a necessary requirement for human and national progress. It is in recognition of the importance of primary education that many nations across the globe, including Nigeria have been making efforts to ensure its universalization. The fundamental objective behind their respective educational programmes was to increase access to primary so that all children of primary school age are in school. The critical nature of this level of education made the Federal Government of Nigeria to declare it free, compulsory and universal (FRN, 2004). This was a quantum shift in the effort to make basic education free for all and accessible. To ensure unhindered access to this level of education, one fundamental strategy to achieve this noble goal is school mapping.

School mapping is an essential aspect of educational planning and a critical strategy for realizing educational goals and objectives. It is the continuous, systematic and rational process of siting and rationalizing educational facilities for the purpose of ensuring that they are provided in a way that set educational goals are realized. School mapping is basically all about 
school network which is dynamic in response to the dynamic nature of the environment it serves. It requires that educational facilities are systematically and rationally located such that the age-group within the population for which it is targeted may use the facilities to their maximum advantage (Kaufman \& Herman, 2002). The major role of school mapping is to set up a rational school network to meet educational demand of the society. This role comes into play majorly when large-scale reform or significant expansion of an educational system takes place. It is also a continuous process. School mapping. To a very great extent, guarantees high access level, mitigates out-of-school syndrome. In other words, it seeks to ensure effectiveness and economy as much as possible while taking into account the overall objectives. In essence then, school mapping has the double function of ensuring greater access and equality of education opportunities and at the same time ensuring economic rationality in education provision.

The Universal Basic Education (UBE) programme is a response to the global call for unfettered access to basic education. It is to be seen as part of Nigeria's attempt to join the international community by giving effect to her commitment to the world trends in the field of basic education. The effectiveness and efficiency of this programme cannot be possible if the siting of educational institutions are not well planned. Hence, planning is critical to the entire process, and one of the planning strategies is School Mapping. It is an imperative strategy. School mapping is a tool that helps to plan for better access to education. It provides the requisite conditions for the achievement of universal access. On the above stand, school mapping has special significance for the universalization of access to basic education. Hence, the study sought to determine the level of school mapping for the implementation of the Universal Basic Education programme in Imo State.

The UBE programme is designed to ensure that basic education (primary and junior secondary) is free, compulsory and universal. By this, no Nigerian child of school age should be out of school. It is also an offence for anybody or any group to deny a child access to basic education. By implication, it entails hundred percent enrolment rate, all things being equal. The corresponding high enrolment rate should therefore, be anticipated. The demand for more school places will be a necessary aftermath. No wonder, Ellah (2012) posited that for the massive expansion of education which the UBE programme is designed for, to be achieved, the success relies on access. In a study carried out by Ellah (2012) on location factors and primary school attendance and participation in Otukpo Local Government Area of Benue State, it was revealed that public primary school children in Otukpo Local Government Area have low radius per child meaning the pupils cover short distances to school, which is an indication of high level of access to school places. Another study conducted by Obasi and Madu (2015) on school mapping and the democratization of basic education in Rivers State, revealed that the mapping of primary schools was adequate but they were not regularly and rationally mapped. Secondary schools (junior) were mapped but the mapping was of low level and not regularly and rationally mapped. When there is low level of school places, such a condition glaringly will have negative outcomes. This was pointed out by the National Population Commission (2011) that insufficient schools to satisfy demand can lead to overcrowded classrooms.

School mapping can sometimes be inhibited by some factors. Sabir (2013) in his study on school mapping in the light of education reforms in Pakistan found out that the absence of school mapping exercise in the area is because of the following reasons: lack of knowledge of the concerned officials to carry out the activity, the absence of the clear-cut policy direction on what, how and when this activity should be undertaken, and inadequate resources in terms of manpower, infrastructure, and facilities essential to conduct school mapping. It was also found out that the EMIS operation is contributing negligibly to the planning and the school mapping activities and this situation is prevalent at the both provincial and district levels. In yet another 
study carried out by Ochai and Olatunde (2015) on the politics of public secondary school mapping and facilities provision in Benue State, it was found out that there are several ways politics influence the location of public secondary schools. The influence include: political godfatherism influencing the location of schools, establishing school to promote in-genuine philosophy to stay in power, immortalization of national heroes using institutions of learning, and location of schools based on political consideration.

\section{Statement of the Problem}

The belief in the power of education as a veritable instrument for the development of the human person and the society at large has continued to enjoy global acceptance. This is evident in the continued rise in the level of involvement of different governments organisations and individuals especially in the developing nations. On the basis of this conviction, the Federal Republic of Nigeria, launched the Universal Basic Education (UBE) programme in 1999. The UBE programme is designed to ensure that basic education (primary and junior secondary) is free, compulsory and universal. By this, no Nigerian child of school age should be out of school. It is also an offence for anybody or any group to deny a child access to basic education. By implication, it entails hundred percent enrolment rate, all things being equal. The corresponding high enrolment rate should therefore, be anticipated. The demand for more school places will be a necessary aftermath. However, more than a decade after the implementation of the UBE programme in Nigeria, many children of primary school age in Imo State appear to be out of school. There are some school-age children who seem to be either not enrolled in school or failed to complete the programme. This situation is what bothers the researchers. The question therefore is: could this ugly situation be as a result of poor level of access to education facilities? What is the level of primary school mapping in Imo State?

\section{Aim and Objectives of the Study}

The aim of this study is to determine the level of school mapping for the implementation of the Universal Basic Education programme in Imo State. The specific objectives thus were to:

- Determine the level to which primary school mapping is carried out since the implementation of the UBE programme in Imo State

- Investigate the factors militating against effective primary school mapping in Imo State.

\section{Research Questions}

The following research questions guided the study:

- What is the level to which primary school mapping is carried out since the implementation of the UBE programme in Imo State?

- What are the factors militating against effective primary school mapping in Imo State?

\section{Hypotheses}

The following hypotheses were tested at 0.05 level of significance:

- There is no significant difference between the mean responses of the staff of the Ministry of Education and the staff of the Universal Basic Education Board on the level to which primary school mapping is carried out since the implementation of the UBE programme in Imo State

- There is no significant difference between the mean responses of head teachers and the staff of the Universal Basic Education Board on the factors militating against effective primary school mapping in Imo State.

\section{METHODOLOGY}

The study adopted the descriptive survey design. The 1,276 Head Teachers of the primary schools together with the 216 staff of the Imo State Universal Basic Education Board 
(IMSUBEB) and 285 staff of the Ministry of Education (MoE) totaling 1,777 constituted the population of the respondents. The sample size of the respondents was 327 which is $18.4 \%$ of the population. This consisted of 136 head teachers $(42,75$ and 76 respectively from the three education zones), 64 staff of the Imo State Universal Basic Education Board (IMSUBEB) and 70 staff of the Ministry of Education (MoE). These were selected using the stratified random sampling technique for head teachers and the simple random sampling technique for the staff of MoE and IMSUBEB. A validated instrument titled: School Mapping and the Universalization of Basic Education Questionnaire (SMUBEQ) with reliability index of 0.84 was used for data collection. Mean and Standard Deviation were used to analyze the data collected, while z-test statistics was used to test the hypotheses at 0.05 level of significance.

\section{RESULTS}

Research Question 1: What is the level to which primary school mapping is carried out since the implementation of the UBE programme in Imo State?

Table 1: The mean scores of the responses on the level to which primary school mapping is carried out since the implementation of the UBE programme in Imo State

\begin{tabular}{llllllll}
\hline & \multicolumn{2}{c}{$\begin{array}{c}\text { Staff of } \\
\text { MoE }\end{array}$} & \multicolumn{4}{c}{$\begin{array}{c}\text { Staff of } \\
\text { IMSUBE }\end{array}$} \\
$\mathrm{S} / \mathrm{N}$ & $\begin{array}{l}\text { School mapping since the implementation } \\
\text { of the UBE programme }\end{array}$ & $\overline{\mathrm{X}}$ & $\mathrm{SD}$ & $\overline{\mathrm{X}}$ & $\mathrm{SD}$ & $\overline{\mathrm{X}} \overline{\mathrm{X}}$ \\
\hline 1 & $\begin{array}{l}\text { The entire state is comprehensively mapped } \\
\text { as one entity }\end{array}$ & 2.49 & 0.89 & 2.40 & 0.92 & 2.45 \\
2 & The mapping is based on sampled zones & 2.48 & 0.88 & 2.45 & 0.87 & 2.47 \\
3 & The mapping is based on sampled subzones & 2.53 & 0.84 & 2.58 & 0.78 & 2.56 \\
\hline
\end{tabular}

Table 1 indicates that, except item 6 with a weighted mean score of 2.56 which is above the criterion mean of 2.50, the other items 4 and 5 had mean scores of 2.45and 2.47 respectively which are below the criterion mean of 2.50. Hence, the mapping was based on sampled subzones. This indicates a low level of primary school mapping.

Research Question Two: What are the factors militating against effective primary school mapping in Imo State? 
Table 2: The mean scores of the responses on the factors militating against effective primary school mapping in Imo State.

\begin{tabular}{|c|c|c|c|c|c|c|c|}
\hline \multirow[b]{2}{*}{$\mathrm{S} / \mathrm{N}$} & \multirow[b]{2}{*}{ Factors variables } & \multicolumn{2}{|c|}{ Head teachers } & \multicolumn{2}{|c|}{$\begin{array}{l}\text { Staff of } \\
\text { IMSUBE }\end{array}$} & \multirow[b]{2}{*}{$\bar{X} \bar{X}$} & \multirow[b]{2}{*}{ Remarks } \\
\hline & & $\bar{X}$ & SD & $\bar{X}$ & $\mathrm{SD}$ & & \\
\hline 1 & Over politicization of the process & 2.90 & 0.91 & 2.97 & 0.90 & 2.94 & Agreed \\
\hline 2 & $\begin{array}{l}\text { Lack or poor policy framework/ } \\
\text { guidelines }\end{array}$ & 2.87 & 0.92 & 2.83 & 0.92 & 2.85 & Agreed \\
\hline 3 & $\begin{array}{l}\text { Non-involvement of educational } \\
\text { planners }\end{array}$ & 2.95 & 0.89 & 2.98 & 0.85 & 2.97 & Agreed \\
\hline 4 & No site feasibility study conducted & 2.78 & 0.97 & 2.72 & 0.94 & 2.75 & Agreed \\
\hline 5 & $\begin{array}{l}\text { Lack of proper assessment from } \\
\text { the Ministry of Education }\end{array}$ & 2.89 & 0.98 & 2.66 & 0.96 & 2.78 & Agreed \\
\hline 6 & $\begin{array}{l}\text { Difficult terrain (hilly, roverine, } \\
\text { rural areas) }\end{array}$ & 2.75 & 0.96 & 2.59 & 1.00 & 2.67 & Agreed \\
\hline 7 & $\begin{array}{l}\text { Lack of technical facilities like } \\
\text { Global Positioning System }\end{array}$ & 3.01 & 0.94 & 3.03 & 0.92 & 3.02 & Agreed \\
\hline 8 & Lack of trained manpower to & & & & & & \\
\hline 9 & $\begin{array}{l}\text { Operate the equipment } \\
\text { Poor funding }\end{array}$ & $\begin{array}{l}2.98 \\
3.09\end{array}$ & $\begin{array}{l}0.93 \\
0.90\end{array}$ & $\begin{array}{l}3.00 \\
3.06\end{array}$ & $\begin{array}{l}0.88 \\
0.93\end{array}$ & $\begin{array}{l}2.99 \\
3.08\end{array}$ & $\begin{array}{l}\text { Agreed } \\
\text { Agreed }\end{array}$ \\
\hline
\end{tabular}

Table 2 shows that all the identified factors have their weighted mean values above the criterion mean of 2.50 . Hence, all the items are accepted as the militating factors to effective primary school mapping in Imo State.

\section{Hypotheses}

$\mathbf{H O}_{1}$ : There is no significant difference between the mean responses of the staff of the Ministry of Education and the staff of the Universal Basic Education Board on the level to which primary school mapping is carried out since the implementation of the UBE programme in Imo State.

Table 3: Z-test of difference on the responses of the staff of the Ministry of Education and the staff of Imo State Universal Basic Education Board with respect to the level to which primary school mapping is carried out since the implementation of the UBE programme in Imo State

\begin{tabular}{lcccccccc} 
Respondents & $\mathbf{N}$ & $\overline{\mathbf{X}}$ & SD & df & z-cal & z-crit & Sign. Level & Decision \\
\hline Staff of MoE & 70 & 2.49 & 0.88 & & & & & \\
& & & & 132 & 0.12 & 1.96 & 0.05 & NS
\end{tabular}

$\begin{array}{llll}\text { Staff of IMSUBEB } \quad 64 & 2.47 & 0.86\end{array}$

Table 3 indicates that the calculated z-value is 0.12 which is less than the critical z-value of 1.96 at 132 degree of freedom and at 0.05 level of significance. Hence, the study failed to reject the hypothesis.

$\mathbf{H O}_{2}$ : There is no significant difference between the mean responses of head teachers and the staff of the Universal Basic Education Board on the factors militating against effective primary school mapping in Imo State. 
Table 4: Z-test of difference on the responses of the Head Teachers and the staff of Imo State Universal Basic Education Board with respect to the factors militating against effective primary school mapping in Imo State.

\begin{tabular}{lcccccccc} 
Respondents & $\mathbf{N}$ & $\overline{\mathbf{X}}$ & SD & df & z-cal & z-crit & Sign. Level & Decision \\
\hline Head Teachers & 193 & 2.52 & 0.89 & & & & & \\
& & & & & & & & \\
& & & & 255 & 0.07 & 1.96 & 0.05 & NS \\
Staff of IMSUBEB & 64 & 2.51 & 0.92 & & & & & \\
\hline
\end{tabular}

Table 4 shows that the calculated z-value is 0.07 which is less than the critical z-value of 1.96 at 255 degree of freedom at 0.05 level of significance. Hence, the hypothesis was retained.

\section{DISCUSSION OF FINDINGS}

It was revealed by the findings that the level of primary school mapping since the UBE programme was implemented in Imo State was low. The low level of mapping was also found out by Obasi and Madu (2015) on secondary school mapping in Rivers State. Such a condition will obviously have negative effects. This was pointed out by the National Population Commission (2011) that insufficient schools to satisfy demand can lead to overcrowded classrooms.However, the finding is completely different from what Ellah (2012) found out in his study. He found out that in Otukpo Local Government Area, children of public primary school have low radius per child meaning the pupils cover short distances to school, which indicated access of high level nature to school places. The scholar further made a point that for the massive expansion of education which the UBE programme is designed for to be achieved, the success relies on access of high level nature to school places.

The study also revealed some of the problems that militate against effective primary school mapping in Imo State. They are: poor funding, lack of technical facilities like Global Positioning System, lack of trained manpower to operate the equipment, non-involvement of educational planners, over politicization of the process, lack or poor policy framework/guidelines, lack of proper assessment from the Ministry of Education and difficult terrain (hilly, riverine, rural areas). The finding corroborated that of Sabir (2013) who in his study found out that lack of knowledge of the concerned officials to carry out the activity, the absence of the clear-cut policy direction on what, how and when this activity should be undertaken, and no available resources in terms of manpower, infrastructure, and facilities essential to conduct school mapping are some of the factors militating against school mapping in the study area. In the same vein, Ochai and Olatunde (2015) in their study found out that there are several ways politics influence the location of public secondary schools. The influence include: political godfather influencing the location of schools, establishing school to promote in-genuine philosophy to stay in power, immortalization of national heroes using institutions of learning, and location of school based on political consideration. These factors inhibit the proper mapping and rationalization of educational facilities.

\section{CONCLUSION}

On the basis of the findings, it was concluded that:

- School mapping since the implementation of the UBE programme is based on sampled subzones, which indicates that the level of mapping is low.

- Over politicization of the process, lack or poor policy framework/guidelines, noninvolvement of educational planners, no site feasibility study conducted, lack of proper assessment from the Ministry of Education, difficult terrain (hilly, riverine, rural areas), 
lack of technical facilities like Global Positioning System, lack of trained manpower to operate the equipment and poor funding are the militating factors to effective primary school mapping in Imo State.

\section{RECOMMENDATIONS}

Based on the findings and conclusions, the following recommendations were made:

- The Government should as a matter of necessity carry out comprehensive school mapping to cater for the demand effect of the UBE programme.

- More professionals in school mapping should be trained and adequate mapping equipment be provided.

- Adequate policy on school mapping should be put in place

- The government should ensure that negative politics should be eliminated from the provision and rationalization of school facilities.

\section{References}

Ellah, W.A. (2012). Location factors and primary school attendance and participation in Otukpo Local Government Area of Benue State. Unpublished Master's Dissertation, University of Port Harcourt, Port Harcourt, Nigeria.

Federal Republic of Nigeria (2004). National policy on education. Abuja: NERDC Press.

Kaufman, R., \& Herman, J. (2002). Educational planning strategic tactical and operational. Lanhalm MD: Rownan \& Littlefield Education.

National Population Commission, (2011). Results of the early grade reading assessment (EGRA) in Hausa, Nigeria Northern Education Initiative (NEI). Durham, NC: RTI International. [P\&E; QUAN; ASSESS]

Obasi, K.K., \& Madu, O.M. (2015). School mapping and the democratization of basic education in Rivers State. Nigerian Journal of Educational Administration and Planning, 15(2), 513-526.

Ochai, G.O., \& Olatunde, O.H. (2015). Politics of public secondary school mapping and facilities provision in Benue State. Nigerian Journal of Educational Administration and Planning, 15(2), 418-431.

Sabir, M.M. (2013). School mapping in the light of education reforms in Pakistan. American Journal of Educational Research, 1 (8), 279-282.

World Conference on Education for All, (1990). World declaration on education for all - framework for action: Meeting basic learning needs. Paris: UNESCO. 